\title{
Knowledge of Green Practices Adoption and Infusion among Employees' of Selected Manufacturing Firms in Ogun State, Nigeria
}

\author{
Oludele Mayowa Solaja $^{1 *}$, Obatunde Bright Adetola ${ }^{1}$, Bamidele A. Badejo ${ }^{2}$ And Emeka E. Okafor ${ }^{1}$ \\ ${ }^{I}$ Department of Sociology, Olabisi Onabanjo University, Nigeria \\ ${ }^{2}$ Department of Geography, Olabisi Onabanjo University, Nigeria \\ *Corresponding Author : postgraduatescholar@gmail.com
}

\begin{tabular}{llll} 
Article history & & \\
\hline Received & Received in revised form & Accepted & Available online \\
15 February 2019 & 25 November 2019 & 20 December 2019 & 30 December 2019 \\
\hline
\end{tabular}

\begin{abstract}
This study investigates the knowledge of green practices adoption and infusion among employees of selected manufacturing companies in Ogun State, Nigeria. The study adopts a descriptive design in which qualitative (in-depth interview and key informant interview guide) and quantitative (questionnaire) methods were used for data collection. The reason for the triangulation of methods is to capture the social and cultural dynamics of the research problem. Multistage sampling techniques were employed in selecting respondents for the study. A total of 321 respondents were utilized in gathering the quantitative data while four (4) key informant interviews and eight (8) in-depth interviews were used for the collection of qualitative data. Descriptive statistics (frequency count and percentage distribution) and qualitative content analysis were deployed in analysing the data. The sociodemographic of the respondents showed that all had some level of formal education. The findings of the study also revealed that a majority $(84.7 \%)$ of the respondents had some level of knowledge about green practices adoption and infusion in their organizations however a significant proportion (15.3\%) of the respondents are still lacking sufficient understanding of green practices adoption and infusion as indicated in the study organizations. The study, therefore, concludes that improved awareness and education on every aspect of green practices infusion and adoption is still needed among employees of manufacturing companies in Nigeria in order to achieve the desired sustainable development goals by the year 2030 .
\end{abstract}

Keywords: Development, Green practices, Knowledge, Manufacturing firms, Nigeria

\section{Introduction}

Development is a fundamental and desirable goal of every individual, group or nation; therefore, whatever can enhance it is always welcomed. In the same vein, whatever has the capacity or potential to retard it is always avoided where possible. This undisputable fact spurred the growing interest in proenvironmental practices also known as green practices by the social stakeholders (individuals, communities, governments, scientists, conservative groups, industries and the media legal and governmental regulations) in the context of averting the pressing social and physical problems (i.e. environmental pollution, desertification, degradation, climate change, etc.) confronting both developed and developing societies. What these problems have in common is that they negatively affect human comfort, socio-economic growth as well as environmental sustainability across the world.

Accordingly, green practices adoption and infusion became inevitable in industrialized countries as developmental approaches to address the issue of environmental pollution, desertification, degradation and climate change. As indicated in recent studies, many industrialized countries like USA, Canada, Malaysia, Japan, China, India, Mexico, Brazil, Indonesia, Nigeria and South Africa at varying degree have revolutionized their industrial and nonindustrial sectors of the economy with green practices [1-5].Green practices are pro-environmental practices such as purchasing eco-friendly products, producing renewable goods, recycling, using pollution abatement equipment tree planting, and efficient waste management techniques in order to reduce the rate of carbon emissions, resource misuse, waste generation and other environmental hazards associated with socio-economic activities[6, 7]. In a simple term, green practices can be described as ecofriendly consumption and production practices whose adoption (the process by which green practices are embraced by business organizations) and infusion (the range at which green practices are used by business organizations) will ultimately reduce environmental impact of socio-economic activities and promote sustainable development for present and future generations.

Considering the prospects of green practices adoption and infusion in averting the risks of environmental degradation, desertification, pollution and climate change worldwide, there has been much interest in researches that focused on green practices implementation in recent times. According to [7] there are five different dimensions of green practices 
namely; internal environmental management (the practice of increasing environmental performance as a strategic organizational imperative for senior and mid-level managers); technology integration (include tacit knowledge sharing, technical training, and modified systems that are used to monitor green practices and outcomes); logistics management (integrated life-cycle management of green practices flowing from the supplier, through to manufacturer, customer, and closing loop with reverse logistics); customer focus (cooperation with customers that promote the design and development of customer's friendly environmental practices); and supplier focus (cooperation with suppliers for the purpose of developing products and services that are environmentally acceptable). Combination of each dimension of green practices in an organization represents a complete green practices adoption and infusion while incomplete or partial green practices adoption and infusion denote otherwise.

Further review of literature revealed that there are many research foci on green practices adoption $[8,9,10-15]$ and green practices infusion [6, 16-22] within organizations. However, what is lacking in contemporary literature are empirical studies that focus on the knowledge of green practices adoption and infusion in all sectors of the global economy. The reason being that green practices as a concept of research focus is relatively new especially in the developing countries like Nigeria whose the statistics of the International Energy Agency (2015) ranked 25th of the 100 countries with a high rate of fossil fuel emission globally. This IEA ranking is partly due to the stumpy and dawdling rate of green practices adoption and infusion by manufacturing companies in Nigeria [23 -25]. To further corroborate this assertion, a lot of studies have reported that there are several environmental degradation issues like prolong and extensive deforestation, illegal mining, poor sanitation, inadequate town/urban planning, uncontrolled industrial activities, oil spillage, and gas flaring just to mention few [26, 27-31]. There are many contributing factors to this state of affairs in Nigeria. Some of these contributing factors include; lack of knowledge about benefits and forms of green practices, lack of decision-making power and technical-know, lack of support, etc. Nevertheless, in order to minimize the byzantine effects already generated by the stumpy rate of green practices adoption and infusion by manufacturing firms in Nigeria and to accomplish the sustainable development goals, this study investigates the knowledge of green practices adoption and infusion among employees of selected manufacturing companies in Ogun State, Nigeria.

\section{Material and Methods}

\subsection{Research Design}

This study adopted a descriptive and crosssectional design in which the quantitative (questionnaire) and qualitative (in-depth interview) methods were employed in collecting empirical data from the respondents on the subject matter. The reason for the triangulation of methods is to capture the social and cultural dynamics of the research problem.

\subsection{Participants}

The participants for the study comprised of 500 employees of ten manufacturing companies in four Local Government Areas in Ogun State, Nigeria. The participants were employees in the following Departments (Procurement and Logistics, Sales and Marketing, Production and Quality Control, Environmental Management, Human Resource and Customer's Relations). The reason for the consideration of these departments' lies in the fact that employees who work in those Departments are expected to have in-depth knowledge of the subject matter and would be able to provide useful information for the study. Also, the participants for the study cut across different occupational cadres (junior, intermediary, supervisory and senior management cadre) which were selected through a multi-stage sampling technique (purposive, stratified and random sampling). The distribution of the sample size is presented in Table 1 .

\subsection{Instrumentation}

A semi-structured questionnaire, in-depth interview and key informant interview guide were used in this study. The questionnaire contained openended and close-ended questions that surround the study objectives. Also, the questionnaire was divided into two sections; section A inquires about the sociodemographic attributes of respondent such as the age, educational qualification, religion, sex etc. Section B contains items on the knowledge of green practices adoption and infusion. The response options were structured following yes or no and a rating scale. The validity of the instruments was determined by face and content review performed by two experts in test and measurement. Moreover, the interview guide contains set of questions relating to the subject matter was used as a plan to keep the conversation focused on the topic while giving the informant room to freely express his/her perception on the content of the discussion. 
Table 1: Distribution of Sample Size by Each Manufacturing Company

\begin{tabular}{llcc}
\hline Selected Manufacturing companies & LGAs & Samples & Percentage $(\%)$ \\
\hline Procter \& Gamble & Ado-Odo/Ota (Agbara) & 66 & 13.2 \\
Shonghai Packaging & Ado-Odo/Ota & 21 & 4.3 \\
Tower Aluminum & Ado-Odo/Ota & 42 & 8.3 \\
Nigerian Breweries & Ado-Odo/Ota & 34 & 6.7 \\
Pure Chemicals & Ado-Odo/Ota & 18 & 3.5 \\
Lafarge Wapco Cement & Ewekoro & 60 & 12.2 \\
Pato foods & Ewekoro & 18 & 3.5 \\
De Olympic Construction Company & Ewekoro & 9 & 1.8 \\
Dangote Cement Plant & Egbado-North (Ibese) & 152 & 30.5 \\
Wempco Steel Mills & Obafemi-Owode & 80 & 16.0 \\
& (Magboro) & 500 & 100 \\
\hline Total & & & \\
\hline
\end{tabular}

Source: Field Survey, 2017

\subsection{Inclusion and Exclusion Criteria}

The selection process was guided by inclusion and exclusion criteria in order to ensure that qualified individuals and targeted manufacturing companies are considered for partaking in the study. The utilization of inclusion and exclusion criteria in a research study has been recognized as part of the main principles of conducting an empirical study (Bhandari, Kanojia, \& Pillai, 2002). The inclusion and exclusion criteria for the present study are shown in table 2 below:

Table 2: Inclusion and Exclusion Criteria

Inclusion Criteria $\quad$ Exclusion Criteria

Senior and junior employees of selected Individuals who are not the staff of the selected manufacturing manufacturing companies; those who are companies or those who are not working in the selected working within selected departments in the departments or those who are not knowledgeable about the manufacturing companies; and they are research problem at hand knowledgeable about the subject matter.

Source: Field Survey, 2017

\subsection{Procedure for Data Collection}

The participants for the study were administered the questionnaires with the help of two trained research assistants. The collected questionnaires were scored and the data obtained from them were analysed to achieve the purpose of the study. On the whole, it took the researcher and assistants two months to administer and collect the distributed questionnaires. This due to the bureaucratic nature of corporate organizations and the need to observe the ethical considerations associated with the study. A total of 321 (out of 500) copies of questionnaires were duly filled and returned, giving a return rate of $64.2 \%$. Also, four (4) key informant interviews and eight (8) in-depth interviews were conducted among environmental officials and head of departments in the selected study organizations. Both quantitative and qualitative data were collected between July and September 2017 as part of a larger study on the factors influencing adoption and infusion of green practices towards the sustainable environment by manufacturing companies in Ogun State, Nigeria.

\subsection{Data Analysis}

The data collected were analysed using descriptive statistics (frequency counts and percentages) to analyse the quantitative data while content analysis was used to analyse the qualitative data so as to establish the respondent views about the phenomenon under study.

\subsection{Ethical Issues in Data Collection}

Ethical principles which include voluntary participation, anonymity, and confidentiality were strictly observed in the course of this study. First and foremost, approval was sought from each head of the department understudy. While the consent of the prospective respondents was also obtained before the instrument was distributed to them. Also, every respondent was made to know that they are free to back out of the study at any point in time. The respondents were briefed about the expected outcomes or benefits of the study so that their participation in the study can be totally voluntary. The information obtained from the respondents was used for academic purpose only and the identities of 
the respondents were kept anonymous and strictly confidential.

\section{Results and Discussion}

3.1. Socio-Demographic Variables of the Respondents

The socio-demographic characteristics of respondents showed that $238(74.1 \%)$ were males and
$83(25.9 \%)$ were females. This sex distribution shows that there are more males than the females' participants in the study. This result also reflects the point that Nigerian society is a patriarchy society where male gender dominates the public sphere of society. Besides, men are seen as breadwinners in most African societies hence, their preponderance at the organizational level [32].

Table 3: Socio-Demographic Variables of the Respondents

\begin{tabular}{|c|c|c|c|}
\hline Gender & Option & Frequency & Percentage \\
\hline & Male & 238 & 74.1 \\
\hline & Female & 83 & 25.9 \\
\hline & Total & 321 & 100.0 \\
\hline \multirow[t]{8}{*}{ Age range } & Option & Frequency & Percentage \\
\hline & $19-23 y r s$ & 46 & 14.3 \\
\hline & $24-28 y r s$ & 80 & 24.9 \\
\hline & 29-33yrs & 48 & 15.0 \\
\hline & 34-38yrs & 93 & 29.0 \\
\hline & $39-43 y r s$ & 33 & 10.3 \\
\hline & $44 \mathrm{yrs}$ and above & 21 & 6.5 \\
\hline & Total & 321 & 100.0 \\
\hline \multirow[t]{7}{*}{ Level of Education } & Option & Frequency & Percentage \\
\hline & Primary education & 21 & 6.5 \\
\hline & Secondary education & 63 & 19.6 \\
\hline & NCE/OND & 166 & 51.7 \\
\hline & HND/ B.Sc. degree & 65 & 20.2 \\
\hline & Others & 6 & 1.9 \\
\hline & Total & 321 & 100.0 \\
\hline \multirow{6}{*}{$\begin{array}{l}\text { Years spent residing in the community or } \\
\text { working in the organization }\end{array}$} & Option & Frequency & Percentage \\
\hline & Less than a year & 75 & 23.4 \\
\hline & $1-5 y r s$ & 121 & 37.7 \\
\hline & 6-10yrs & 100 & 31.2 \\
\hline & $11 \mathrm{yrs}$ and above & 25 & 7.8 \\
\hline & Total & 321 & 100.0 \\
\hline
\end{tabular}

Source: Field Survey, 2017

Also, $46(14.3 \%)$ of the respondents were between the age bracket 19-23years, 80 (24.9\%) were between 24-28 years, 48 (15.0\%) were between 29-33 years, 93 (29.0\%) were between 34-38 years, 33 (10.3\%) were between $39-43$ years and $21(6.5 \%)$ were 44 years and above. It depicts that an appreciable number of the respondents were aged within the economically active population. Moreover, the level of education of the respondents shows that those with primary education 21 (6.5\%), secondary education 63 (19.6\%), NCE/OND $166(51.7 \%), \mathrm{HND} / \mathrm{B} . \mathrm{Sc}$. degree $65(20.2 \%)$ as well as those with other qualifications $6 \quad(1.9 \%)$. The educational status of the respondents indicates that a greater proportion of the respondents had a formal education with at least a primary school leaving qualification. The result also shows that the majority of the respondents are NCE/OND holders. In addition, the distribution of the years spent by the respondents in the organization showed that 75 (23.4\%) of the respondents have spent less than a year, $121(37.7 \%)$ have spent 1 5yrs, 100 (31.2\%) have spent 6-10yrs while 25 (7.8\%) have spent $11 \mathrm{yrs}$ and above in their various organizations. Unfortunately, the result did not show the percentage of those who have previously worked in another organization before joining the present organizations however, the result reveals that most of the respondents had been working in the selected organizations for more than 5 years which also indicates that they are adequately qualified by the inclusion criteria set by the study to take part in the research. Therefore, we can infer that the information gathered from them is based on their understanding of the social realities around them. 


\subsection{Major Findings}

The information gathered from the respondents in accordance with the stated research objectives were presented in this section. Since the World Summit in Rio de Janeiro in 1992, the impression that business organizations including manufacturing companies produce more emissions and toxic waste during the manufacturing processes of their products demanded that every manufacturing company in today's era of sustainable development should ensure that they carry out their operations cleanly. As part of the process of ensuring cleaner production, manufacturing firms are encouraged to adopt green practices in their modus operandi $[33,7]$. Unfortunately, the rate of adoption of green practices by business organizations in developing countries has been reported to be very low and slow $[33,3]$. In Nigeria, a lot of manufacturing companies who have adopted green practices (partially or completely) in their mode of operations have been identified with some impelling factors that stimulate the adoption of green practices $[24,1]$. Thus, this section investigates the respondents' knowledge of green practices as well as the types of green practices adopted in the selected manufacturing companies. Hence, information gathered during the organizational phase is presented in Table 4 below.

The information presented in Table 4 above reveals that $84.7 \%$ of the employees' respondents are aware of green practices as pro-environmental practices in the organization while $15.3 \%$ have never heard about it. Thus, it can be deduced that a majority of the employees' respondents claimed that they know that green practices are sustainable environmental conducts adopted in their various business and industrial organizations. This practically indicates that the majority of the respondents are aware of green practices (GPs) and hence have certain information about GPs. This finding corroborates [34] who reported that manufacturing companies are becoming more conscious of their processes and how it affects the environment which as a result prompted Malaysian manufacturing companies to consider the need for adopting and implementing green supply chain. Similarly, the finding supports [9] who submitted that the emergence of the environmental crisis in China led to some moral doldrums that stipulated the adoption of a variety of environmental management practices in many companies operating in China following the government enactment of several environmental regulations. More so, the finding of the study agrees with [35] who observed that the awareness of sustainable development and green practices are gradually increasing globally. However, in contrast to the above views, the finding also points out that some of the respondents claimed that they have never heard about green practices before which indicates that more effort is still required to increase the level of awareness of green practices among business organizations in Nigeria. To buttress this point, a key informant affirmed that: "the idea of going-green is fast spreading among business organizations in today's global system, however, the spread of green practices is somewhat slow in Nigerian manufacturing industry due to four primary reasons; low level of awareness, lack of finance, cost, and technological know-how (KII/Director/Ministry of Environment/Abeokuta/2017). Also, during one of the in-depth-interview sessions held with some respondents, an interviewee stated that "unfortunately, the level of adoption of green practices among manufacturing companies in Ogun State, Nigeria is significantly low because there are still many manufacturing companies that are not aware of the green innovations and practices. More so, not all the employees that work in the manufacturing firm especially in Ogun State, Nigeria are aware of green practices. How would they not engage in environmental pollution or degradation? (IDI/Head/HR and Customer Relations/Sango/2017).

The statement above attests to the fact that some manufacturing companies in Ogun State, Nigeria are aware of green practices; however, there is utmost need for the non-governmental organizations whose interest as key actor come closer to the community/customers to create more activities around awareness, especially if the government is not forthcoming due to her interest as a key actor, (which may inhibit green practices in the study area) in order to increase the adoption rate.

Table 4: Knowledge of Green Practices among the Employees of Selected Manufacturing Firms

\begin{tabular}{lll}
\hline Have you heard about green practices as pro-environmental practices before? & Frequency & Percentage \\
\hline Yes & 272 & 84.7 \\
No & 49 & 15.3 \\
Total & 321 & 100.0 \\
\hline How long have you heard about green practices? & Frequency & Percentage \\
\hline Less than a year & 63 & 23.2 \\
1-5 years & 171 & 62.9 \\
6 years and above & 38 & 13.9 \\
Total & 272 & 100.0 \\
\hline In your own view, do you think your organization has adopted green practices? & Frequency & Percentage \\
\hline Yes & 259 & 95.2
\end{tabular}




\begin{tabular}{lll} 
No & & ojs.pps.unsri \\
Total & 13 & 4.8 \\
\hline If yes, what kind of green practices do your organization adopted? & 272 & 100.0 \\
\hline Internal Environmental Management & Frequency & Percentage \\
Technology Integration & 93 & 35.9 \\
Logistic Management & 58 & 22.4 \\
Customer Focus & 56 & 21.6 \\
Supplier Focus & 13 & 4.8 \\
Internal Environmental Management and Technology Integration & 5 & 1.8 \\
Total & 34 & 5.1 \\
A major source of knowledge about green practices & 259 & 100.0 \\
\hline Through the media & Frequency & Percentage \\
Through colleagues and supervisors & 41 & 15.1 \\
Workshop, training, conference and seminar & 63 & 23.2 \\
Total & 168 & 61.7 \\
\hline Does green practices reduce industrial emissions and environmental challenges & 272 & 100.0 \\
\hline Yes & Frequency & Percentage \\
No & 215 & 79.0 \\
Total & 57 & 21.0 \\
\hline Do green practices encourage the application of new innovation and ideas for & 272 & 100.0 \\
manufacturing companies & Frequency & Percentage \\
\hline Yes & & \\
No & 235 & 86.4 \\
Total & 37 & 13.6 \\
\hline Do green practices improved material management and social impact of & 272 & 100.0 \\
manufacturing activities & Frequency & Percentage \\
\hline Yes & & \\
No & 183 & 67.3 \\
Total & 89 & 32.7 \\
\hline Do green practices enhance the company's reputation and corporate image & 272 & 100.0 \\
\hline Yes & Frequency & Percentage \\
No & 240 & 88.2 \\
Total & 32 & 11.8 \\
Source: Fild Surver & 272 & 100.0 \\
\hline
\end{tabular}

Source: Field Survey, 2017

Furthermore, the result in Table 4 shows that $23.3 \%$ of the respondents claimed to have heard about green practices for a period of less than a year; $62.9 \%$ stated that they have heard about green practices for a period of 1-5yrs; and 13.9\% affirmed that they have heard about green practices for a period of 6yrs and above. Thus, it can be inferred that the majority of the employees have heard about green practices for a period of $1-5 \mathrm{yrs}$ and they might have also engaged in eco-friendly activities that symbolize green practices in their various organizations. To buttress this submission, for instance, an interviewee who claimed to have known about green practices for about five years now described the term as: series of activities such as cleaning of the work environment, planting of flowers, adoption of green innovation as well as reduction of anthropogenic emissions in work organization. (IDI/Head/Procurement and Logistics /Ewekoro/2017). Also, another interviewee who heard about green practices for a period less than a year described the term as: the use of clean technologies, abatement plant, safety gadgets, alternative energy and efficient waste management system so as to reduce environmental degradation and to ensure healthy environmental condition. (IDI/Head/Environmental

Management/Agbara/2017).

From the responses above, it is evident that the period at which employees' respondents had known about green practices does not impact on their behaviour of green practices. In an attempt to ascertain the certainty of green practices adoption in their various companies, $95.2 \%$ of the employees' respondents affirmed that their companies have adopted green practices while $4.8 \%$ disputed it. Hence, it can be deduced that a majority of the respondents disclosed that their companies have adopted green practices (either partially or completely). Consequently, upon this result, employees' respondents who affirmed that their companies have adopted green practices were asked to state the type of green practices adopted in their various companies. The result in Table 4 reveals that $35.9 \%$ of the employees' respondents stated that their organizational type of green practices revolved around internal environmental management, $22.4 \%$ affirmed that their organizational type of green practices centred on technology integration, $21.6 \%$ 
declared that their organizational type of green practices focused on logistics management, $5.1 \%$ stated that their organizational type of green practices involved the combination of internal environmental management, technology integration and logistics management, $4.8 \%$ said that their organizational type of green practices are customer focused while 1.8\% affirmed that their organizational type of green practices are supplier focused. Thus, it can be inferred that a majority of the respondents disclosed that their organizational type of green practices revolves around internal environmental management (IEM), technological integration (TI) and logistics management (LM). Other forms of green practices (like customer focus and supplier focus) were given little or less significant consideration in the selected manufacturing companies (as shown in the result presented in Table 4. The inference that can be drawn here is that most of the manufacturing companies adopted the type of green practices that are mainly specified for issuance of the ISO 14001 certificate. This may be due to the fact that it is compulsory that a manufacturing company must attain ISO 14001 endorsements before commencing operations. This finding corroborates [34], and [36] who noted that ISO 14001 certification is to certify that a company's processes are green but it does not certify that the whole operational chain is green. Similarly, the finding supports [37] who opined that "ISO 14001 provides a framework, which guides firms to implement Environmental Management System (EMS) to improve environmental performance only within a firm's operation boundaries instead of throughout the whole operational chain of the manufacturing company". However, the implication for relying on ISO 14001 standards as a form of green practice implementation in the manufacturing industry is that less attention will be given to corporate social responsibility (CSR), and other practices that are supposed to improve the condition of people and societal institutions. To reinforce this point of view, a key informant who had worked as a health and environmental officer for about 35 years stated that: "A majority of the manufacturing companies that are operating in Ogun State, Nigeria are owned by businessmen and women from countries like India, Lebanon, Israel, Malaysia, China, Germany, United Kingdom etc... They usually consider the profit they want to make from doing business in Ogun State, Nigeria without thinking about the impact of their operations on the green vegetation of Ogun State. They don't care about the percentage of land that has been tampered upon; a number of trees that have been cut down as well as the natural resources that are on the ground when they commence their business activitiesThere are a lot of factories built here without EIA (Environmental Impact Assessment) and when we try to apprehend them they make use of their political affiliation to manoeuvre their ways...Frankly speaking, what seems to be their main priority is the profit-making and maintenance of their internal work environment (KII/Director/Environmental Health Dept/ Ado-Odo Ota/ 2017).

Another key informant interviewee revealed that: "some of them (manufacturers) are trying when it comes to adopting green practices. Here in Ogun State, we have a greater number of foreign investors, experts, and manufacturers who understand the idea of green practices right from where they came from... Although they always try to run away from adopting green practices because they believe it is costly to install or operate green technologies in Nigeria....It has not been easy monitoring and inspecting manufacturing companies in Ogun State because manufacturers always want to cut down running cost by adopting cheaper technology so that they can make more profits. (KII/Scientific Officer/Ministry of Environment/Abeokuta/ 2017).

From the above responses, it is evident that most manufacturing companies in Ogun State, Nigeria are profit oriented and they try as much as possible to reduce the cost of production at the expense of their corporate environmental responsibility. This attitude of most manufacturing companies is a challenge to the interests of other stakeholders particularly the non-governmental organizations, customers as well as community residents who have a strong passion for corporate environmental performance in today's era of sustainable development agenda. However, to an extent, poor attitude to corporate environmental performance might not be a challenge to the government interest since an increase in organizational profits translates to an increase in taxes and revenue generation.

Moreover, the failure to adopt green practices by the manufacturing firms as a result of profit maximization reflects that a reasonable number of manufacturing companies operating in Nigeria are yet to translate green knowledge to green corporate behaviour. Also, going by the respondents' responses one can affirm that a majority of the manufacturing companies are still in the behavioural modification stage (stage 3) of the behavioural change process. Furthermore, it is clear that the majority of the manufacturing companies in Ogun State, Nigeria are owned by foreigners who believe that once they have secured ISO 14001 permits for their businesses, and the internal surroundings of the organization is clean; they are in little or no obligation to ensure that they perform other corporate environmental responsibilities. However, the Nigeria experience 
may not be as that of countries like China, Japan, Britain, the United States of America, Canada, South Africa, and so on where manufacturing companies adopt advance green practices, processes and products in their operations and still ensure that they perform their corporate environmental obligations [9, 33, 38].

Moreover, it is evident that the majority (67.3\%) of the respondents agreed that green practices adoption and infusion improve material management and social impact of manufacturing activities while $32.7 \%$ disagreed with the statement. The implication here is that with green practices adoption and infusion most manufacturing companies may develop new and efficient production technique which guarantee judicious utilization of resources right from the point of production, packaging, distribution, consumption and reverse waste management. This represents a significant transition from traditional manufacturing strategy (in the era prior to green revolution) to modern-day alternative green manufacturing strategy. Moreover, the respondents were asked to indicate whether green practices implementation encourages the application of new innovation and ideas for manufacturing companies. The result shows that the bulk of the respondents $(86.4 \%)$ strongly agreed to the statement, while $13.6 \%$ were of contrary opinion. More so, a majority of the respondents $(88.2 \%)$ were of the view that green practices adoption and infusion is a good strategy to enhance company's reputation and corporate image, while $11.8 \%$ were doubtful. Investigating the issue further, key informant interviews (KIIs) were conducted to know the benefits of green practices adoption and infusion by manufacturing companies in Nigeria. Based on thirtyfour years of working experience, an environmentalhealth officer asserted that "Honestly speaking, a lot of advantages can be derived from adopting green practices by manufacturing companies. First and foremost, manufacturing activities always generate a lot of unwanted materials that might result to air, water or land pollution if not properly managed. The management there is what green practices are meant to do for any manufacturing company who adopted it. It helps to reduce most of the social and health risks that are generated as a result of manufacturing. Green practices reduce the rate at which emissions are disposed into the atmosphere and it helps to address the issue connected with climate change which has become very important for both developed and developing countries today. Researchers have shown that the environment we have today was not the same with the one we had as far back as early nineteen century because a lot of alterations have been done due to growth in human interactions with nature. I can vividly remember that in the 70s when I was still at college, we used to be so concern with issues of hygiene and sanitation because there was nothing like climate change then. But today, it has been climate change, the spread of deadly diseases, flood, water pollution, air pollution, land pollution etc. that are now confronting every one of us. Therefore, green practices adoption has enormous benefits that I cannot exhaust in a moment and these benefits are essential to human, plants and animals sustainability (KII/Director/Environmental Health Dept./Ado-Odo Ota 2017). Similarly, a senior environmental health officer at Ewekoro Local Government Area said: Concerning the benefits associated with the adoption of green practices by manufacturing companies, I will say there are many however, green practices ensure that there is efficient utilization of resources, energy conservation, safety at work, reduction of industrial pollution and environmental degradation as well as profit-maximization (KII/Officer/Environmental Health Dept./Ewekoro/2017).

In addition to the above responses, a scientific officer in the ministry of environment stated that: Scientifically, green practices adoption by manufacturing companies is essentially good. This is because it guarantees the quality of management, organizational workforce, work systems and community well-being. Also, green practices help to mitigate the impact of manufacturing activities on the environment and societal institutions (i.e. family, education, religion, economy, and politics). For instance, some of the health issues that affect people as an individual or as a group in an industrial environment can be resolved with the implementation of green practices or clean technologies (KII/Scientific Officer/Ministry of Environment/Abeokuta/2017).

From the above responses, it could be deduced that the adoption and infusion of green practices by manufacturing companies have initiated a paradigm shift towards a new manufacturing strategy which has enormous benefits to manufacturers, employees, customers, government, and other stakeholders. For instance, it has improved environmental and social conditions of people (by reducing the rate of pollution arising from manufacturing activities) within and around the industrial environment, created employment opportunities for ecopreneurs, innovations and improved people's access to ecofriendly products and alternative energy. As a matter of fact, green practices implementation has brought about social change which is the alteration of social structure including consequences and manifestations embodied in norms, values, and cultural practices of individuals and groups $[20,8]$. In this context, green 
practices had encouraged sustainable consumption pattern, lifestyle, efficient resource management and utilization, quality management practices, environmental risk reduction, as well as sustainable development. However, it should be noted that adequate knowledge of green practices adoption and infusion is a fundamental tool that can direct the course of addressing the problem of environmental pollution, desertification, climate change, and poverty in Nigeria.

\section{Conclusion and Recommendations}

This research work investigates the knowledge of green practices adoption and infusion among employees of selected manufacturing companies in Ogun State, Nigeria. The study employs both qualitative and quantitative data in providing insight into the research problems. The findings of the study also revealed that a majority of the respondents had some level of knowledge about green practices adoption and infusion and a significant proportion of the respondents still lack sufficient understanding of green practices adoption and infusion at the time of conducting this study. This state of affairs, if not urgently challenged, might continue to generate developmental challenges such as pollution, resource depletion, anthropogenic emission, disease outbreak, desertification, urban decay, and climate change with a significant effect on human comfort and social development in contemporary Nigerian societies and beyond.

Based on the findings of the study, the paper recommends the followings:

1. Manufacturing companies must ensure that they put in place necessary green management practices and pollution abatement plant before embarking on business operations. This will enable them to effectively fulfil predetermined corporate environmental responsibility and attract more patronage from the customers.

2. They should also go beyond adopting ISO 14001 principle by adopting a more green manufacturing strategy that is specifically associated with their production techniques.

3. Manufacturers association should embark on open seminars and workshops for manufacturing companies in Nigeria in order to enhance the level of awareness and knowledge of green practices.

4. The government should engage in constant and regular visitation to manufacturing companies to see how their work systems are being carried out in order to ensure full compliance and commitment to environmental rules and regulations.

5. As access to sufficient financial resource is an important aspect of green practices adoption and infusion in manufacturing firms, the government should adequately fund the bank of the industry so that manufacturing companies especially those that are fully owned by Nigerians can access fund to enhance green practices adoption and infusion in their various industries.

\section{REFERENCES}

[1] Alliyu, N., \& Solaja, M.O (2016). The Political Economy of Nigeria's Green Practices Adoption in the Era of Sustainable Development Goals (SDGs). Social Studies. Albanian Institute of Sociology (AIS). Albania. Vol. 10(2) pp. 99-114.

[2] Leimona, B., Amaruzaman, S., Arifin, B., Yasmin, F., Hasan, F., Agusta, H., Sprang, P., Jaffee, S., \& Frias,J.(2014) Indonesia's 'Green Agriculture' Strategies and Policies: Closing the Gap between Aspirations and Application. World Agroforestry Centre. Occasional Paper. Pp:23-67.

[3] Yacob P., Aziz N., Makmor M. \& Zin A., (2013) The Policies and Green Practices of Malaysian SME. Global Business and Economics Research Journal, (2013) 2 (2), p.52-74

[4] Studer, S., Welford, R. \& Hills, P. (2006). Engaging Hong Kong businesses in environmental change: Drivers and barriers. Business Strategy and the Environment, 15. Pp.416-431.

[5] United Nations Industrial Development Organization (2006) Report on the Review of African Sustainable Industrial Development. UNIDO.

[6] Ho, Y-H., Lin, C-Y., \& Tsai, J-S. (2014) An Empirical Study on Organizational Infusion of Green An Empirical Study on Organizational Infusion of Green Practices in Chinese Logistics Companies. Journal of Economic and Social Studies, 4 (2) pp. 159-189

[7] Conding, J., Zubir, M.F.A., Hashim, A.S., \& SriLanang, A. N. (2012). A Proposed of Green Practices and Green Innovation Model in Malaysia Automotive Industry. Environmental Management and Sustainable Development,1(2), pp.90-100.

[8] Green, Jr. K. W., Zelbst, P. J., Meacham, J., \& Bhadauria, V. S. (2012). Green supply chain management practices: Impact on performance. An International Journal, 17 (3): pp.1-44.

[9] Lin, C. Y., \& Ho, Y. H. (2011). Determinants of green practice adoption for logistics companies in China. Journal of Business Ethics, 98(1), pp.67-83. 
[10] Rottenburg, \& Zyglidopolos (2007) Determinants of Environmental Innovation Adoption in the Printing Industry A research monograph of the printer industry service at RIT.

[11] Henriques, I., \& Sadorsky, P. (2007) Environmental technical and administrative innovations in the Canadian Manufacturing Industry. Bus. Strategy. Environ., 16(2) pp.119-132.

[12] Zhu, Q., Sarkis, J. \& Geng, Y., (2005) Green supply chain management in China: pressures, practices and performance. International Journal of Operations and Production Management 25(5): pp. 449.

[13] Del Brio J. A., \& Junquera B., (2003) A review of the literature on environmental innovation management in SMEs: Implications for public policies. Technovation, 23(12), pp. 939-948.

[14] Theyel, G. (2000). Management practices for environmental innovation and performance. International Journal of Operations \& Production Management, 20 (2), pp. 249266.

[15] Zsidisin, G.A. \& Hendrick, T.E. (1998), "Purchasing's involvement in environmental issues: a multi-country perspective", Industrial Management \& Data Systems, Vol. 7, pp. 313-320

[16] Yu, S., Mishra, A. N., Gopal, A. \& Mukhopadhyay, T. (2009). IT infusion and its performance impacts: An empirical analysis of e-procurement in the service industry. International Conference on Information Systems (ICIS) 2009 Proceedings. Paper 121. December 15-18, Phoenix, Arizona.

[17] Yan, H., \& Fiorito, S. S. (2007). CAD/CAM diffusion and infusion in the US apparel industry. Journal of Fashion Marketing and Management, 11(2), pp. 238-245.

[18] Taylor, J., \& McAdam, R. (2004). Innovation adoption and implementation in organizations: a review and critique. Journal of General Management, 30(1), pp. 17-38.

[19] Fichman, R. G. (2001). The role of aggregation in the measurement of IT-related organizational innovation. MIS Quarterly, 25(4), pp. 427-455.

[20] Fussel, L., \& Georg, S. (2000). The institutionalization of environmental concerns: making the environment perform. International Studies of Management and Organization, 30(3), pp. 41-58.
[21] Winn, M. I., \& Angell, L. C. (2000). Towards a process model of corporate greening. Organization Studies, 21(6), pp. 1119-1147.

[22] Stead, E., McKinney, M.M., \& Stead, J.G. (1998). Institutional environmental performance in U.S. industry: is it happening and what if it does not? Business Strategy and the Environment, 7 (5), pp. 261-271

[23] Eruola A. O., Ufoegbune G. C., Eruola A. O., Awomeso J. A., Adeofun C. O., Idowu O.A. \& Abhulimen, S. I.(2011) An assessment of the effect of industrial pollution on Ibese River, Lagos, Nigeria. African Journal of Environmental Science and Technology Vol. 5(8), pp. 608-615.

[24] Aribigbola, A., Fatusin, A.F., \& Fagbohunka, A (2012). Assessment of Health and Environmental Challenges of Cement Factory on Ewekoro Community Residents, Ogun State, Nigeria. American Journal of Human Ecology. Vol. 1(2):pp51-57

[25] Bada, B. S., Olatunde, K. A., \& Oluwajana A. (2013). Air quality assessment in the vicinity of Cement company. International Research Journal of Natural Sciences, 1(2), pp.34-42.

[26] Solaja, MO., Omobowale, AO., \& Alliyu, N. (2015). The Dimension of Environmental Pollution in Lagos Metropolis Nigeria. Journal of Sustainable Development in Africa 17 (3), pp.1-20

[27] Weli, E. V. (2014). Atmospheric Concentration of Particulate Pollutants and its Implications for Respiratory Health Hazard Management in Port Harcourt Metropolis, Nigeria. Civil and Environmental Research. 6(5). pp.11-17.

[28] Adimekwe, S. C (2013). The Impact of Environmental Pollution in Imo State: A case study of Okigwe Local Government Area. Journal of Educational and Social Research 3, 5 doi: 105901/Jesr.2013.V3n5p79

[29] Akanni, C.O. (2010) Spatial and seasonal analyses of traffic-related pollutant concentrations in Lagos Metropolis, Nigeria" Afr. J. Agric. Res., 5(11): pp.1264-1272.

[30] Adewole, A.T. (2009) Waste management towards sustainable development in Nigeria: A case study of Lagos state. International NGO Journal. Vol. 4 (4), pp. 173-179.

[31] Atolagbe, A.M.O \& Tanimowo, N.B (2006): Noise Pollution in Nigeria Urban Centres: A focus on Ogbomoso town. In Fadamiro, Olujimi, and Atolabge (Eds) Urban Environment Sustainability: Interventions and Responses. Shalom Publishers, Akure. 77-87 
[32] Otite, O. \& Ogionwo, W (2006) An Introduction to Sociological Studies. Ibadan: Heinemann Educational Books (Nig) Plc.

[33] Babiak, K., \& Trendafilova, S. (2011). "CSR and environmental responsibility: motives and pressures to adopt green management practices." Corporate Social Responsibility and Environmental Management 18(1): 1124.

[34] Shamsuddin, A., Wahab, E., Abdullah, N.H. \& Qazi, F.H. (2017). Green Supply Chain Implementation In Manufacturing Industry: A Case Study. International Journal of GEOMATE, 13, (38), pp.31-37

[35] Hieu, M.V., \& Rasovska, I. (2017) A proposed conceptual model of green practices impacting on the tourism businesses and their performances-A case of Phu Quo Island Vietnam, Business Trends, Vol. 7 (1):76-87
[36] ElTayeb, K.T., Zailani, S \& Jayaraman, K (2010) The examination on the drivers for green purchasing adoption among EMS 14001 certified companies in Malaysia. Journal of Manufacturing Technology Management, 21, pp. 206-225

[37] Handfield, R.B., Walton, S.V., Sroufe, R. \& Melnyk, S.A. (2002), "Applying environmental criteria to supplier assessment: a study in the application of the analytical hierarchy process", European Journal of Operational Research, Vol. 141 (1), pp. 70-87.

[38] Sarkis, J. (2001) Manufacturing's Role in Corporate Environmental SustainabilityConcerns for the New Millennium. International Journal of Operations \& Production Management, 21, pp. 666-686. 